\title{
The Power of Words in Shakespeare's Julius Caesar: An Insight into Analyzing Julius Caesar from the Perspective of the Logical Fallacies
}

\author{
Abdullah K. Shehabat ${ }^{1}$, Baker Bany-Khair ${ }^{2}$, Mohammad Qararah², Zaydun Al-Shara ${ }^{3}$ \\ ${ }^{1}$ Tafila Technical University-Department of English Language and Literature, Jordan \\ ${ }^{2}$ Hashemite University-Department of English Language and Literature, Jordan \\ ${ }^{3}$ University of Jordan-Department of Foreign Languages, Jordan \\ Correspondence: Abdullah K. Shehabat, Tafila Technical University-Department of English Language and Literature, \\ Jordan.
}

Received: November 19, 2021

Accepted: December 27, 2021

Online Published: December 28, 2021

doi:10.5430/elr.v11n1p1

URL: https://doi.org/10.5430/elr.v11n1p1

\begin{abstract}
:
This research aims at utilizing the knowledge of logical fallacies in analyzing Shakespeare's masterpiece Julius Caesar. Spotting these fallacies in the characters' actions and speeches is more likely to expand our horizon by grasping what is hidden between the lines and beyond the surface dialogue, thus revealing the true intentions of the characters and the subliminal messages beyond what they say. To achieve this goal, an explanation for each fallacy is provided. Also, various examples of fallacies committed by Donald Trump in the American presidential debate in addition to some of his fallacious tweets and other examples are thoroughly analyzed. It is found that by providing meticulous analysis for the fallacies under question readers would be protected from being victimized to any ambiguous and/or language literary interpretation.
\end{abstract}

Keywords: logical fallacies, Donald Trump, Julius Caesar, Shakespeare, fallacy

\section{Introduction}

A word is a double-edged sword. Once it plunges aimlessly, the intended message will deviate from its track causing a misinterpretation on the part of the addressee. Metaphorically speaking, weighing words appropriately in due course and place is a skill that none can master perfectly unless well-utilized. Whatever success one aspires to achieve in life the subtle use of language remains the peculiarity of success. Therefore, what has clung in the memory of the current generation about the accomplishments of Caesar, Socrates, Martin Luther King, John Kennedy, and Mahatma Gandhi is their phraseologies and fragments that have become refrains and cliques up to these days. However, language might be used as a deceptive instrument to impose questionable agendas or deleterious intentions using logical fallacies. Impelled by the role and the significance of language and words in the past and present, language use will be studied in light of logical fallacies.

With reference to matters of timelessness and language, Shakespeare's works are solid masterpieces that never wither. Evidently, his cultural heritage and literary works, still considered the epitome of all qualities applauded in eloquence and the power of language, have lived more than Shakespeare himself has. Until today, many phrases and words of his plays, e.g., "to be or not to be", which possess a gorgeous aesthetic value, have entered within English lexicons to be widely used by the entire speaking English community at large. For that reason, the researchers selected Shakespeare's Julius Caesar, being replete with instances of the dexterous use of language for various goals. The crème de la crème of Shakespeare's plays, Julius Caesar will be the entry for the world of fallacies.

\section{Review of Related Literature}

In his study entitled "Verbal Power Duel: Verbal Combat Strategies in Shakespeare's Julius Caesar: Brutus Versus Antony," Behnam (2009) provides a brief analysis where readers would observe how Antony, magically, turned the table upside down on Brutus using the same structure of Brutus' oration crowd for his favor. He concludes that Brutus and Antony's oration is cunningly systematized to be structured like "a language dual," namely, attacks and counter-attacks (3). 
Cheetham's study (2017) entitled "Rhetorical Flaws in Brutus' Forum Speech in Julius Caesar A Carefully Controlled Weakness?" deeply explains how Antony's speech is superior to Brutus' by examining the breaches and flaws that enabled Antony to triumph, a term Cheetham calls "The contest of language". Cheetham relies on some rhetorical studies concerning examining rhetorical forms in Brutus' oration after Caesar's death. Cheetham concludes his research by shedding light on the role of structural and rhetorical analysis in understanding the implied messages Shakespeare intentionally manipulated to weaken the speech of Brutus in comparison with that of Antony. In addition, he explains how non-rhetorical analysis fails to capture powerful messages, thus proving how Antony's choice of words and style of speech is superior to Brutus. Further, drawing upon the same theme of the impact of rhetorical analysis and in particular to the notion of the powerfulness of a fallacy, Enos, et al. (2017) have thoughtfully tackled the power of a fallacy in federal courts and trials and how it affects verdicts with their research entitled "The Negative Effect Fallacy: A Case Study". Their research concludes that the negative effect of fallacy is typically used to dismiss "actual or potential quantitative information (126).

It is worth mentioning that in the same field of the role of fallacies and power of words, the most controversial American president Donald J. Trump cunningly utilized words for the sake of his presidential campaign. In his research titled "Us and Them: A Descriptive Analysis of Donald Trump's Campaign Speeches," McClay (2017) sheds light on how Trump constructs three of his political campaign speeches to represent the reality of the American status quo to boast his ideology. He points out that Trump's speech addressed to American citizens is equipped with words that are personally and emotionally oriented. McClay concludes that Trump's speech structure is manipulated to "unfairly and dishonestly draw false connections with immigrants, foreigners and his political opposition, and the very real problems that Americans face with respect to jobs and crime within the ideology frame of Racism" (49)

\section{Objectives and Method}

The current paper is intended to separate the logical fallacies from Shakespeare's rhetoric language because very few, if any, barely combined both in one research. This research, therefore, deals with how logical fallacies affect our analysis of a literary work so as to provide a better understating for the implications embedded in between the tangible text and the regular lines. Having realized and gleaned adequate knowledge of logical fallacies, the big picture of untold and unsaid details regarding the reason beyond the characters' actions, behaviors, and their actual intentions get clearer. To do so, some excerpts from Julius Caesar will be analyzed from the perspective of fallacies. Therefore, enough understanding of the fallacy used is necessary to digest the accompanying analysis in the data section. This is why the fallacies in question are explained and equipped with examples from the former president Donald J. Trump and his competitor Hillary Clinton during their presidential debates prior to the last round of elections.

Undoubtedly, Donald J Trump is deemed as one of the most controversial figures in America. An aspect of his controversy stems from his language, which is systematically manipulated to impose his ideologies cunningly as his maneuvering tactics in the presidential debate and his campaign speeches. Reporting Trump's news, The New York Times (2017) stated that "at least one false or misleading claim per day on 91 of his first 99 days (Saturday is Day 100)." Also, The Washington Post (2018) stated in an article entitled "President Trump has made more than 5,000 false or misleading claims" that in one single day, Trump publicly made 125 false or misleading statements in a period of time that did not exceed 120 minutes. Therefore, the present researchers use examples of Trump vs. Clinton presidential debate along with Trump's speeches and tweets beside other miscellaneous resources as the primary references to provide concrete and practical illustrative examples of the dexterous use of language and fallacies.

\section{Data Analysis}

The data section demonstrates each fallacy in parallel with the quotes taken from Shakespeare's Julius Caesar that they match/mismatch with. A thorough elucidation of each fallacy is also provided. To gain more understanding of the fallacy vis-à-vis the quote's, each quote is explained briefly by showing how the fallacious structure of the quote contributed to altering the line of events (Table 1). Finally, we inferred some of the consequences and/or expected distortion that might well occur in case the fallacy isn't recognized, which would negatively distort average readers' perception and impressions about the characters and events. 
Table1: Data Analysis

\begin{tabular}{|c|c|c|c|c|}
\hline $\begin{array}{l}\text { Item } \\
\text { No. }\end{array}$ & Fallacy type & The source & Quotes with fallacies & Speaker \\
\hline \multirow[t]{3}{*}{1.} & \multirow[t]{3}{*}{$\begin{array}{r}\text { False dilemma } \\
\text { (Black or } \\
\text { white) }\end{array}$} & $\begin{array}{r}\text { Donald J Trump } \\
\text { presidential } \\
\text { announcement speech }\end{array}$ & $\begin{array}{r}\text { "And therefore think him as a serpent's egg Which } \\
\text { hatch'd would as his kind grow mischievous, And } \\
\text { kill him in the shell." }\end{array}$ & Brutus \\
\hline & & $\begin{array}{r}\text { Donald J Trump } \\
\text { presidential } \\
\text { announcement speech }\end{array}$ & $\begin{array}{r}\text { "Why, man, he doth bestride the narrow world } \\
\text { Like a Colossus, and we petty men } \\
\text { Walk under his huge legs and peep about } \\
\text { To find ourselves dishonourable graves." }\end{array}$ & Cassius \\
\hline & & $\begin{array}{r}\text { Donald J Trump } \\
\text { presidential } \\
\text { announcement speech }\end{array}$ & $\begin{array}{l}\text { " Dwell I but in the suburbs } \\
\text { Of your good pleasure? If it be no more, } \\
\text { Portia is Brutus' harlot, not his wife." }\end{array}$ & Portia \\
\hline 2. & $\begin{array}{r}\text { Anecdotal } \\
\text { evidence }\end{array}$ & $\begin{array}{r}\text { A tweet of Donald J } \\
\text { Trump on Twitter website }\end{array}$ & $\begin{array}{l}\text { For once, upon a raw and gusty day, } \\
\text { The troubled Tiber chafing with her shores, } \\
\text { Caesar said to me 'Darest thou, Cassius, now } \\
\text { Leap in with me into this angry flood, } \\
\text { And swim to yonder point?' etc..." }\end{array}$ & Cassius \\
\hline \multirow[t]{2}{*}{3.} & & $\begin{array}{r}\text { Bertrand Russell and } \\
\text { Mustafa'a Logical } \\
\text { Fallacies }\end{array}$ & $\begin{array}{l}\text { "When could they say till now, that talk'd of Rome, } \\
\text { That her wide walls encompass'd but one man? } \\
\text { Now is it Rome indeed and room enough, } \\
\text { When there is in it but one only man." }\end{array}$ & Cassius \\
\hline & & $\begin{array}{r}\text { Bertrand Russell and } \\
\text { Mustafa'a Logical } \\
\text { Fallacies }\end{array}$ & $\begin{array}{r}\text { Our course will seem too bloody, Caius Cassius, } \\
\text { To cut the head off and then hack the limbs, } \\
\text { Like wrath in death and envy afterwards; } \\
\text { et purgers, not murderers...etc..." }\end{array}$ & Brutus \\
\hline 4. & $\begin{array}{r}\text { Complex } \\
\text { question } \\
\text { fallacy }\end{array}$ & & $\begin{array}{r}\text { Brutus oration in front of Roman's nation after } \\
\text { killing Caesar }\end{array}$ & Brutus \\
\hline
\end{tabular}

\subsection{False Dilemma Fallacy: Black or White Thinking}

There has never been a consensus regarding the name of this kind of fallacy. All-or-nothing fallacy, false dichotomy, the either-or fallacy, either-or reasoning, fallacy of false choice, the fallacy of false alternatives, black-and-white thinking, the fallacy of exhaustive hypotheses, bifurcation, excluded middle, no middle ground, polarization are all names related to it (retrieved October $30^{\text {th }}, 2020$ from www.logicallyfallacious.com). In fact, all these names share the commonality of the sense of restriction to only a couple of two extremist choices black or white, no grey area in the middle. In his book How to Win Every Argument, Pirie (2006) defines 'false dilemma fallacy' as an "either/or situation when in reality there is a range of options" (19). He further elucidates that in this fallacy "the mistake is made by the denial of extra choices .... and to limit choice." (20). It's like asking someone to determine either he is with you, or against you, no moderate joint to be reached. The pattern of this fallacy according to Mustafa in his book Logical Fallacies (162) is as follows,

1. Either claim $\mathrm{X}$ is true or claim $\mathrm{Y}$ is true (when $\mathrm{X}$ and $\mathrm{Y}$ could be both false) .

2. Claim $\mathrm{Y}$ is false.

3. Therefore, claim $\mathrm{X}$ is true.

We here argue that this pattern of reasoning is fallacious and invalid. Having $Y$ as always false does not necessarily imply the truthfulness of $X$. In Logical Fallacies, Mustafa points out that the above structure is fallacious owing to the implied premises that there are only two options to choose from (163). In his presidential announcement speech, Donald Trump committed a black and white fallacy he said "I beat China all the time." Mentioning the verb "beat" in this statement implies that there is an equation that consists of two parts: either a winner or a loser! When it comes to international trade and /or the cycle of politics, no one can argue that he /or she can be a winner. According to Molly, 
trade deals among countries are of mutual interest, rather than a single one (n.p). In other words, the implied dilemma drawn is either one votes for Trump and wins all of Americans or votes for his opponents then all Americans would suffer from constant loss. Indeed, this claim is far from the sound argument. Instead of substantiating evidence or information on how he is eager to beat China economically, he benefits from the false dilemma fallacy with the aim to massively catastrophe the status quo for his sake and fear-mongering American population to vote for him.

Quotes Analysis

False dilemma fallacy played a vital role in altering the chain of events in Shakespeare's Julius Caesar with Brutus' stance of his bosom friend. This alternation subsequently brought about a pivotal turning point in the fate of Rome at large. Indeed, it is intriguing how Cassius manages to devastate the seemingly ever-lasting intimate bond between Brutus and Caesar with such a mere pretext of being Caesar's ambition. The assumption of "ambition" is extremely conservational and doubtful to a great extent due to lacking all kinds of reasoning to support. That is why Brutus postulated the veracity of getting into the murky water of a bloodshed conspiracy against his steadfast friend. In fact, Cassius pictures Rome's status quo for Brutus as a black-or-white image. If one does not pick white, then the black of unwelcomed ensuing repercussions will follow. This is what Cassius cunningly endeavors to instill into Brutus' head by steering him toward a predetermined destination, at the end of which the stigma of ambition and tyranny is attached and clung to Caesar.

The next quote in question is a part of soliloquy in which Brutus catastrophizes the whole matter of Caesar's alleged ambition into only a couple of odds. He mentions that "It must be by his death, and for my part I know no personal cause to spurn at him but for the general. He would be crowned.". As far as this quote is concerned, readers are bombarded with two options here: Either people kill Caesar or else he kills them. Apparently, Brutus has no neutral options regarding this point: not thinking of a grey area of the ample potentials to restrain Caesar's ambition, given that no tangible proof on this accusation is substantiated and this claim by Cassius is still shrouded in mystery. Regardless of his apparent good intention of pursuing the decency of Rome as a top priority, Brutus is labeled with the stigma of a "friend murder." After all, murdering a friend because of a marginal slight possibility of a trivial chance of hazard, that the overall odds to take place are unlikely, is by no means justifiable .In this quote, whether mainly influenced by Cassius or not, the impact of this fallacy on Brutus is clear in his inner dialogue making him see the whole matter as to kill or be killed, to be a murderer or a victim.

The process of swaying Brutus to such a lunatic decision is gradually and cunningly plotted by Cassius; constantly relentless defamation of Caesar is needed first. Cassius, in turn, spares no effort to do so. He misrepresents reality by polarizing the courtiers of the king as if they were powerless and worthless while Caesar is powerful and valuable. The excerpt below elaborated more. It read,

Why, man, he doth bestride the narrow world

Like a Colossus, and we petty men

Walk under his huge legs and peep about

To find ourselves dishonorable graves (ACT 1. SC. 2., p. 21)

Here, Cassius extremely exaggerates when he presents only the two remote sides of the image: everything or nothing. It can be inferred that Caesar gains more superiority and authority for being the king of Rome. Such black and white thinking of everything-or-nothing is attributed to erroneous reasoning which aims at escalating Brutus' furious stance against Caesar. Cassius depicts Brutus and himself as dwarfs under the huge legs of Caesar which is of course a fallacious technique that aims at narrowing the scope of vision of Brutus to establish an unequal distorted comparison in which Brutus feels himself less and hates Caesar more.

On the other hand, Shakespeare's discourse could never be devoid of the feminine voices. Concerning the feminine contribution to the powerfulness of eloquence of language, Portia is very adept at utilizing figurative language in either-or-fallacy in an endeavor to disclose the secret Brutus was concealing. When Brutus evades talking about it, the mesmerizing reply of Portia was as thus,

Dwell I but in the suburbs

Of your good pleasure? If it be no more,

Portia is Brutus' harlot, not his wife (ACT 2. SC. 1, p. 69)

Apparently, Brutus is confined by Portia's adroit response by telling her she is inevitable and inescapable, yet hardly trying not to be swayed by such powerful eloquence and cunning figurative language. Indeed, once dismantling and 
putting aside the metaphorical and figurative structure, the black and white fallacy clearly manifests itself. What Portia implies is that either Brutus tells Portia the secret of his own and Portia be an honorable wife, or else, Portia and a prostitute would become alike. The fallacious logical pattern according to the fallacy in this quote is as follows:

- Choose a wife or prostitute (Implied premises)

- A prostitute is to please rather than to share love or feelings.

- A wife is the woman who one could keep secrets with.

- If one does not tell his wife secrets then, predictably, she is a mere prostitute.

In order to maintain both his secret and his wife, Brutus must instantly act so as not to fall a victim to this fallacious gimmick. In fact, once responding to and/or distorting such a fallacy, one should take into account exposing the other options in the middle to be deliberately ignored. If it is too tough and all-sided encompassed with eloquence and metaphor seeming inescapable as Portia astonishingly did, modeling a similar pattern of eloquence and reversing the impact of the fallacy and throwing it back again is how to evade this devilish fallacy in this situation showing the opponent how absurd his original argument is. What Portia does was to confine Brutus' choices into only two options (tell what he hides or else would not be a decent and beloved wife) and veils that with appreciating the use of words and figures of speech in order to disclose that secret, therefore, to encounter such situation one has to cunningly redirect the same fallacy in his response to the original statement. To better explain how to respond to this fallacy in particular that of Portia-and-Brutus, below the researchers suggest sample of a reply to undermine such a fallacy if they were in Brutus' shoe.

It is a heavy burden even on a foe to throw

So how I, for an honorable wife, would bestow

Once I, in my free will, opt to burden you

With the same for my enemies' even, I am reluctant to do

Then surely must you know you are no more my wife nor much I love you

Here, the present researchers have used the same fallacy to respond to Portia's fallacy putting forward a couple of choices to choose from. To avoid that critical moment, Brutus should necessitate his love of Portia to the secret of the conspiracy and put this forward before Portia to choose from the two fallacious options that this example of undermining this fallacy provides.

\subsection{Anecdotal Evidence}

As the name suggests, the pillar of this fallacy stands on the substitution of evidence with stories and anecdotes. Merriam Webster dictionary defines anecdotal evidence as"evidence in the form of stories that people tell about what has happened to them" (n.p). In his book Attacking Faulty Reasoning (2013), Damer defines 'anecdotal evidence' as the structures that are based entirely on the "personal experience of the arguer or a few people of his or her acquaintance" and added, "[t]he evidences could also be based on a faulty causal analysis of a situation" (37). In light of the preceding definitions, it can be inferred that when void irrelevant anecdotes replace concrete evidence, logic and reasoning collapse as is the example below.

An example of this fallacy is when Trump tweets that "[m]any people are now saying I won South Carolina because of the last debate. I showed anger and the people of our country are very angry!" Trump in his tweet backs up his claim of winning in South Carolina with a so-and-so anecdote Many people are now saying instead of presenting actual figures and statistics (Molly, 2019, n.p)

Fallacy Quotes

Below another quote that presents another fallacious state is illustrated. It reads,

Is now become a god, and Cassius is

A wretched creature and must bend his body

If Caesar carelessly but nod on him.

He had a fever when he was in Spain,

And when the fit was on him, I did mark

How he did shake. 'Tis true, this god did shake! 
His coward lips did from their color fly,

And that same eye whose bend doth awe the world

Did lose his luster. I did hear him groan,

Ay, and that tongue of his that bade the Romans

Mark him and write his speeches in their books-

"Alas," it cried, "give me some drink, Titinius",

As a sick girl. Ye gods, it doth amaze me

A man of such a feeble temper should

So get the start of the majestic world

And bear the palm alone (ACT 1. SC. 2, p. 21)

Impelled by the relentless defamation of Caesar by Cassius, Brutus, with the dagger of treason stabbed his most loyal, close, and intimate kinder spirit, namely, Caesar. For Brutus, to get involved in this distressful and hideous murder, Cassius plots cunningly following a systematic approach including defaming Caesar's bravery, fear-mongering of Caesar's alleged tyranny, and degrading Caesar and elevating Brutus. However, to defame the value of a king who recently comes back triumphant from war is subtle. To achieve that quest by proving the weakness of Caesar for Brutus, he narrates a story of Caesar seeking help from him to survive a flood describing how Caesar then was powerless and helpless comparing him to a sick crying girl. Regardless of the truthfulness of his story, it neither substantiates any evidence nor proves any claim of Caesar, being coward owing to seeking help when he was too paralyzed. Indeed, the function of this anecdotal evidence is to confuse Brutus and to derail the dialogue from the track of logical argument, so solid proofs must be present instead of senseless anecdotes.

\subsection{Loaded Words: Prejudiced Language}

Words do not only disseminate information, knowledge and thoughts but also feelings, senses and attitudes. Therefore, hand-picking our words to parallel with stances and attitudes must fully address statements in turn. Despite the long list of synonyms, a single word might have the stances, feelings and attitudes each seemingly similar synonym vary and deemed as a double-edged sword. In his book, How to Win Every Argument Pirie (2006) views loaded words fallacy as the "words used are calculated to conjure up an attitude more favourable or more hostile than the unadorned facts would elicit, the fallacy used is that of loaded words" (106). Pirie further elucidates that "[i]t is possible to influence the outcome of a judgement by the deliberate use of prejudiced terms" (106). Concerning the subtle difference between synonyms, he explains that

Near synonyms carry subtle nuances of meaning which can be used to influence attitudes to the statement which bears them. The fallacy derives from the fact that these attitudes are not part of the argument. They were conjured up illicitly to achieve more effect than could the argument alone. The extra nuances and the response to them are both strictly irrelevant to establishing the truth or falsehood of what is being said (Pirie 106).

Drawing upon the same theme, in their book The Meaning of Meaning (2014) Ogden and Richards define meaning as "The emotive use of words is a simpler matter, it is the use of words to express or excite feelings and attitudes" (149). They added, "[u]nder the emotive functions are included both the expression of emotions, attitudes, moods, intentions, etc., in the speaker, and their communication, i.e., their evocation in the listener". Ogden and Richards illustrate why emotive language can be misleading sneaky and oriented:

In many cases, moreover, emotive language is used by the speaker not because he already has an emotion which he desires to express, but solely because he is seeking a word which will evoke an emotion which he desires to have; nor, of course, is it necessary for the speaker himself to experience the emotion which he attempts to evoke (149-150).

To further employ and correlate the ideas in Pirie's quotes with that of Ogden and Richards' quotes above, we need to provide a useful example by Johnson and Blair, "In 1948, on a radio program The Brains Trust, Bertrand Russell gave a joke example of an irregular verb conjugation which he calls "emotive conjugation" (160). One of his famous conjugations is "I am firm, you are obstinate, he is a pig-headed-fool" (ibid, 160). Such conjugation reflects the nature of human behavior i.e. the tendency to praise some people more than others. In the previous conjugation, Russel sarcastically shows how one would describe himself in the most elevated positive image and how he would describe those he does not know in a rather neutral image then how one would depict someone he hates in an 
extremely negative image respectively. The adjectives 'firm', 'obstinate' as well as 'pig-headed' with their positive, neutral and negative connotations, respectively, are loaded words, yet cannot be easily restricted to one single meaning. Such words, technically, stand for the same concept, namely, one track-minded. Nonetheless, a common perception when gearing someone is firm or pigheaded is absolutely opposite. This reveals that how the same idea can be viewed from different point of views.

Mustafa, in his book Logical Fallacy, provides a good comparison example of this fallacy. He mentions, "[i]t is for the second time that Brititan is seized coaxing dictatorships [...] It is for the second time we see that Britain plans at keeping an amicable relationship with hard-line regimes" (153). In the first part of the quote, the speaker shows Britain as a criminal who seized coaxing dictatorship. The verb seize implicates that there is an illicit action which is being exposed. Regarding the verb coax, Britain in this example coaxes i.e. eagerly appreciates and longs for the diplomatic relations with dictatorships. Also, hearing the word dictatorships triggers the image of powerfulness of Adolf Hitler in mind. On the other hand, in the second sentence, the issue seems to be less serious and less severe. Instead of seized, coaxing and dictatorships, the euphemistic phraseology: 'plans', 'keeping an amicable relationship and hardline regimes' are replaced, respectively. These verbs and adjectives are intentionally manipulated to evoke the desired impact, thus alleviating the severity of the action. Both statements technically mean the same; the first one tends to be an accusation while the second is as an innocent statement.

\section{Fallacy Quotes}

Cassius makes use of a pun to create an emotive effect with the use of words. In the quote below, Cassius agitates Brutus against Caesar by saying that it was not fair only for one man to rein Great Rome. If really Rome with all the huge walls that surrounds it belongs only for one man, Caesar, then, it is a Room; not the great Rome:

When went there by an age, since the great flood,

But it was famed with more than with one man?

When could they say till now, that talk'd of Rome,

That her wide walls encompass'd but one man?

Now is it Rome indeed and room enough,

When there is in it but one only man.( ACT 1. SC. 2 P.23)

The resemblance in "similar-sounding words" in Rome and Room creates paronomasia effect with the rhyming sound within. This rhetorical effect creates a similar sound and has a great connotative match in between. One of the shades of meanings of Rome is power while room connotes powerlessness. Indeed, the loop between Rome and Room is more likely to affect judgment of what is real and rhetoric. Below, Brutus validates his barbaric 'assassination' euphemisms to soften the hardness of the cruelty of his hideous act of murdering his friend, Caesar. He maintains,

Our course will seem too bloody, Caius Cassius,

To cut the head off and then hack the limbs,

Like wrath in death and envy afterwards;

For Antony is but a limb of Caesar:

Let us be sacrificers, but not butchers, Caius.

We all stand up against the spirit of Caesar;

And in the spirit of men there is no blood:

$O$, that we then could come by Caesar's spirit, And not dismember Caesar! But, alas,

Caesar must bleed for it! And, gentle friends,

Let's kill him boldly, but not wrathfully;

Let's carve him as a dish fit for the gods,

Not hew him as a carcass fit for hounds:

And let our hearts, as subtle masters do,

Stir up their servants to an act of rage,

And after seem to chide 'em. This shall make

Our purpose necessary and not envious:

Which so appearing to the common eyes,

We shall be call'd purgers, not murderers.

And for Mark Antony, think not of him;

For he can do no more than Caesar's arm 
When Caesar's head is off. (ACT 2. SC. 1, p.61)

Apparently, Brutus describes himself and the other traitors' courtiers as sacrificers denying being butchers. In addition, despite the bloodshed scene of those 13 daggers stabbing Caesar, Brutus views it as a boldness act yet denying its barbaric sight where 13 daggers were stabbing the body of one single defenseless man. Brutus further claims that this bloodshed is murder-abolition. Brutus subtly cherry-picks words to justify and therefore alleviate the sense of guilt. Such connotation, the cherry picking, is a mere fallacious type (loaded words) that shows an internal conflict between Brutus' ego to be a king and his conscience toward his bosom friend, the moment when the conscience accuses the ego of being barbaric and wrathfully while the latter, the ego, views it in light of boldness.

\subsection{Loaded and/or Complex Questions}

Anton Chekhov says "The role of the artist is to ask questions, not answer them." However, one sneaky way of posing questions is called yes-no complex questions. It does not matter to answer with either yes or no. In case one thinks from this view, they will fall victims of fallacious trap question which conceals misty presuppositions behind the 'shadowy' yes-no answer. This fallacious yes-no question is a gimmick to admit and confess the implied yet untold presuppositions which are covered with a shroud of simple yes-no answer. Therefore, identifying this fallacy in a question is necessary. A classic example of a loaded question is" Have you stopped beating your wife?" If 'yes', you admit you were. If 'no', then you still are (Pierre: 29). Pierre comments on this example by saying that both options contain an assumption that the hidden question has already been favorably answered. It is this unjustified presumption which constitutes the fallacy. Many questions may be asked, but if the response is expected before it is given a plurium interrogationum has been dedicated (30). According to Mustafa, one of the forms of complex questions is having a couple of statement conjoined with a coordinator like "and" as if the two statements go together as a refrain, while both of them are not necessarily related. The trick here is either one accepts both statements or deny both. However, the fact is that the receiver admits one of them and should not necessarily accept or postulate the other (Mustafa: 185). An example of this is the question "Are you with the freedom of people and issuing weapons carry license?" This question carries two shades of meaning: Freedom of people and issuing a weapon-carry license (Mustafa 168) .

To encounter the aforementioned two-statement-complex question, we need to analyze and identify the concealed implications. The fallacy committed here is misleadingly connected to the freedom of people to issue weapons license. The question implies that either one admits the need to issue a firearms license or else their opinion means that they are with the view of restricting citizens' freedom to do what they think is right. Nonetheless, that is not necessarily true because carrying weapons has deleterious repercussions that might transcend the law itself to deprive individuals of their most crucial right, especially when misused by reckless people. On that ground, one can tell the opponent how his question reflects on the lack of the adequate insight and the actual reasoning by opting to violating law for the sake of legitimizing having dangerous tools. What complex question does here is to inappropriately confuse facts.

\section{Fallacy Quotes}

We here provide a very significant quote spoken in the post of Caesar's death scene by Brutus. The quote reads,

If there be any in this assembly, any dear friend of Caesar's, to him I say, that Brutus' love to Caesar

was no less than his. If then that friend demand

why Brutus rose against Caesar, this is my answer:

--Not that I loved Caesar less, but that I loved

Rome more. Had you rather Caesar were living and

die all slaves, than that Caesar were dead, to live

all free men? As Caesar loved me, I weep for him;

as he was fortunate, I rejoice at it; as he was

valiant, I honour him: but, as he was ambitious, I

slew him." (ACT 3. SC. 2, p.117)

This quote is the oration of Brutus and Antony after Caesar's death which represents one of the eternal examples of the power of persuasion and eloquence. In the quote, Brutus and Antony defend their stance of Caesar in front of the Roman nation. The victorious in this debate wins the public support, therefore, for both, this debate is of utmost significant. Brutus spares no effort in presenting misleading presuppositions in the pistol of the complex question fallacy firing these false presuppositions right into the logic of the crowd. In fact, the question Brutus poses is not as any average innocent question at all. His question "Had you rather Caesar were living and die all slaves, than that 
Caesar were dead, to live all free men?" is a trap well-equipped with emotionally loaded statements and implications. Once subconscious mind postulates this camouflaged trap question as a simple "Yes or No Question," logic fails here, thus leaving the hearer falling a victim for the conclusion which this question submits in the form of a question. Therefore, these hidden presuppositions are problematic. Before extracting these implications, an analysis of the shallow and deep structure of this question is needed first. The questions have a couple of surface statements: Either Caesar is alive and be a salve or he is dead and be free. The fallacy of complex question is committed once necessitating Caesar's life or death for freedom or slavery. There is no concrete joint between both in such arbitrary relationship. The trick here is that there is no grey area where reader in not permitted to take a single statement and discard the other. The problematic implications and hidden presuppositions are:

1- Caesar is ambitious

2- Ambitions lead to tyranny

3- Tyranny gives rise to injustice

4- Injustice leads to slavery

5- If Caesar is dead, his ambition is dead and the tyranny is over

6- If Caesar is alive, his ambitious and slavery will prevail as long as he is alive

Indeed, such small question has all the above-illustrated assumption and presuppositions that look true to some extent. However, it is known that extremism in ambition might lead to tyranny then slavery. What Brutus does is to appeal to the inevitable consequences of the exaggeration on ambition without submitting even a single word how Caesar was or seemed to be ambitious. In a nutshell, instead if substantiating an evidence Caesar is guilty, Brutus gives a sermon about the repercussions of being overambitious.

\section{Conclusion}

Shakespeare's literary work Julius Caesar is a masterpiece that is unquestionably deemed his finest and crème de le crème work. The characters in the play, overtly or covertly, used a number of fallacies like, false dilemma, anecdotal evidence, loaded words, and complex question to deceive each other. These fallacies play a pivotal role in steering not only the characters' action but also the lines of events toward a turning point where Rome was on the edge. This shows how fallacies can be powerful when the reader becomes fully aware of the dual function of these fallacies.

Spotting the black and white fallacy in quotes, where Cassius incites Brutus to nip Caesar and his ambition in the buds before resurrection of that alleged ambition and the impact of this on Brutus concerning Caesar, helps the reader lay the foundation of the shape of his/her own analysis and characterization regrading Cassius and his role in particular. On the same fallacy, the researchers show how demonic this fallacy gets when well-structured and eloquently formed in a part of a quote said by Portia as she tries to disclose the secret of the conspiracy which is a fallacy that Brutus, the great and shrewd leader, was almost trapped by. The researchers have dismantled the implied fallacious structure of Portia's fragmented quote and they have proposed a response/ answer to this fallacious question had they been in Brutus' shoe based on reversing the impact of this fallacy and by throwing it back again toward Portia to curb her appetite so as to make Brutus disclose the secret of conspiracy.

The Second fallacy in this research is the anecdotal evidence where the burden of proof is based on senseless anecdotes and stories that are not in line with logic and reasoning. Cassius utilizes the technique of anecdotal evidence to defame Caesar using this fallacy to undermine his value in Brutus' eyes when he tells a story of the mighty Caesar as he calls for help like a sick girl with the aim at affecting Brutus's stance toward Caesar. Also, this research has dealt with the fallacy of loaded words and how our choice of words is vital to convey not only the meaning but also one's altitudes, feelings and stances. The example quote of fallacy shows how Brutus subtly cherry-picked his words to justify his hideous murder and ease the sense of guilt by utilizing different connotations to serve this aim which are shown in the research. Lastly, the research ends up with the complex question fallacy which conceals misty fallacious presuppositions inside a question. In the post of Caesar's death scene, Brutus sues this fallacy to necessitate Caesar's life or death for freedom or slavery. 


\section{References}

Anecdotal Evidence. Merriam-Webster, Retrieved 23 ${ }^{\text {rd }}$ August, 2020 from https://www.merriamwebster.com/dictionary/anecdotal\%20vidence\#: :text=\%3A\%20evidence $\% 20 \mathrm{in} \% 20$ the $\%$ 20 form $\% 20$ of,based $\% 20$ only\%20on\%20anecdotal\%20evidence

Behnam, A. (2009). Verbal Power Duel: Verbal Combat Strategies in Shakespeare's Julius Caesar: Brutus Versus Antony. KEMANUSIAAN: The Asian Journal of Humanities, 16(1).

Cheetham, D. (2017). Rhetorical Flaws in Brutus' Forum Speech in Julius Caesar: a Carefully Controlled Weakness? Advances in Language and Literary Studies, 8(3), 126-145. https://doi.org/10.7575/aiac.alls.v.8n.3p.126

Damer, T. E. (2013). Attacking Faulty Reasoning: A practical Guide to Fallacy-Free Arguments. Damer, T. E. Boston, MA: Wadsworth, Cengage Learning.

Enos, R. D., Fowler, A., \& Havasy, C. S. (2017). The Negative Effect Fallacy: A Case Study of Incorrect Statistical Reasoning by Federal Courts. Journal of Empirical Legal Studies, 14(3), 618-647. https://doi.org/10.1111/jels.12158

False Dilemma. Logically Fallacious, retrieved 30 ${ }^{\text {th }}$ October, 2020, https://www.logicallyfallacious.com/logicalfallacies/False-Dilemma

Johnson, R. H., \& Anthony, B. (2006). Logical Self-Defense. International Debate Education Association, 2006.

Kessler, G. (2018). President Trump Has Made More than 5,000 False or Misleading Claims. The Washington Post.

McClay, R. (2017). Us and Them: A Descriptive Analysis of Donald Trump's Campaign Speeches. The University of Birmingham, Oral speech.

Molloy, P. (2019). Arguing Is Easy; Persuasion Is Hard: What Donald Trump Teaches Us about Debate. Upworthy, Upworthy, Retrieved $24^{\text {th }}$ January, 2019 from https://www.upworthy.com/arguing-is-easy-persuasion-is-hard-what-donald-trump-teaches-us-about-debate

Mustafa, A. (2007). Logical Fallacies. Retrieved $18^{\text {th }}$ Nov, 2021 from https://www.noor-book.com/en/tag/Logical-fallacies

Ogden, C., \& Richards. L. A. (2014). The Meaning of Meaning. Language Sciences, 1(41), 212-221. https://doi.org/10.1016/j.langsci.2013.10.001

Pirie, M., \& Pirie, M. (2006). How to win every argument: The use and abuse of logic. London: Continuum.

Qiu, L.(2017). Fact-Checking President Trump Through His First 100 Days. The New York Times, 29 Apr. 2017.

Shakespeare, W. (1905). The Tragedy of Julius Caesar. Barbara Mowat and Paul Werstine, eds. UK: Folger Shakespeare Library.

\section{Copyrights}

Copyright for this article is retained by the author(s), with first publication rights granted to the journal.

This is an open-access article distributed under the terms and conditions of the Creative Commons Attribution license (http://creativecommons.org/licenses/by/4.0/). 